\title{
Exploring Competencies of Social Workers in Dealing with Reporting of Domestic Violence Cases
}

Nurfarahizzati Zakaria, Khadijah Alavi \& Siti Marziah Zakaria

To Link this Article: http://dx.doi.org/10.6007/IJARBSS/v12-i1/12102

DOI:10.6007/IJARBSS/v12-i1/12102

Received: 09 November 2021, Revised: 10 December 2021, Accepted: 26 December 2021

Published Online: 18 January 2022

In-Text Citation: (Zakaria et al., 2022)

To Cite this Article: Zakaria, N., Alavi, K., \& Zakaria, S. M. (2022). Exploring Competencies of Social Workers in Dealing with Reporting of Domestic Violence Cases. International Journal of Academic Research in Business and Social Sciences, 12(1), 841-853.

\section{Copyright: @ 2022 The Author(s)}

Published by Human Resource Management Academic Research Society (www.hrmars.com)

This article is published under the Creative Commons Attribution (CC BY 4.0) license. Anyone may reproduce, distribute, translate and create derivative works of this article (for both commercial and non0-commercial purposes), subject to full attribution to the original publication and authors. The full terms of this license may be seen at: http://creativecommons.org/licences/by/4.0/legalcode

Vol. 12, No. 1, 2022, Pg. $841-853$

Full Terms \& Conditions of access and use can be found at http://hrmars.com/index.php/pages/detail/publication-ethics 


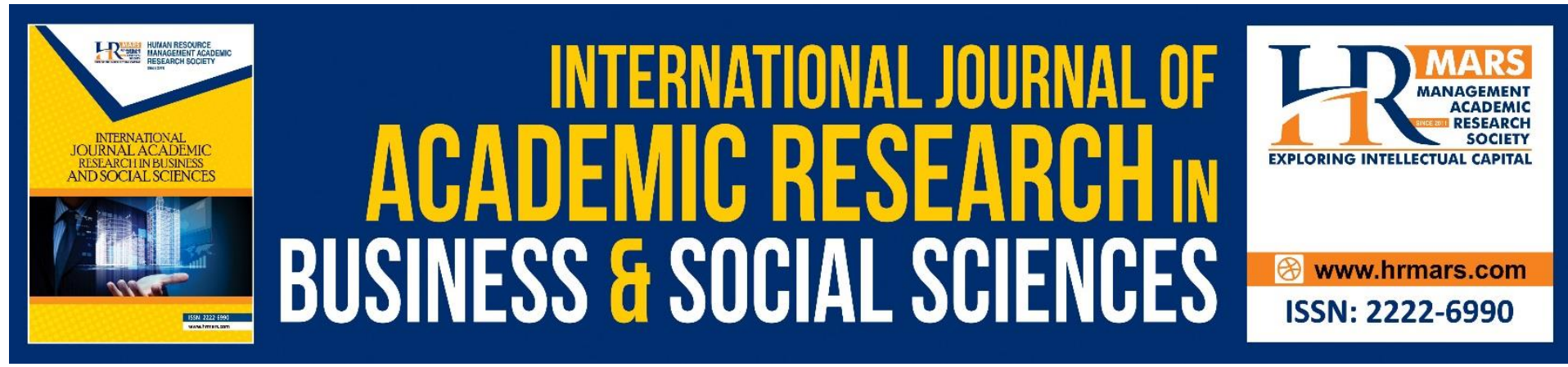

\title{
Exploring Competencies of Social Workers in Dealing with Reporting of Domestic Violence Cases
}

\author{
Nurfarahizzati Zakaria, Khadijah Alavi \& Siti Marziah Zakaria \\ Center for Research in Psychology and Human Well-Being, Faculty of Social Science and \\ Humanities, Universiti Kebangsaan Malaysia, 43600 Bangi, Selangor, Malaysia \\ Corresponding Author: khadijah@ukm.edu.my
}

\begin{abstract}
Factors of inconsistency in the reporting of domestic violence cases due to lack of knowledge and exposure to the violence case reporting techniques have been outlined. The COVID-19 pandemic had impacted family well-being with an increase in domestic violence cases during PKP. In 2020, 3,080 cases of domestic violence were reported to the Royal Malaysian Police (PDRM) from the period of the Movement Control Order (PKP) starting March 18 to the Recovery Movement Control Order (PKPP) and the Conditional Movement Control Order (PKPB) until 31 October 2020. The purpose of the study is to explore the skills of social workers in handling domestic violence case reporting techniques. Qualitative design is chosen guided by the case study approach. The justification for choosing this approach is due to the complex issue of domestic violence, thus the need to use in-depth interviews to obtain clearer, richer, and more detailed information. This study was conducted in the district of Hulu Langat, Selangor. The criteria in determining the sample and identifying the respondents are based on the objectives of the study. The result of the study suggests that many domestic violence cases are difficult to prove due to inconsistencies in case reporting between the victims of the cases, the hospital, police, welfare officers, and the lawyers.

Keywords: Procedures, Social Worker, Domestic Violence, Family, Competency
\end{abstract}

Introduction

The COVID-19 pandemic has restricted community movement through the Movement Control Order (PKP) from March 18 to the Recovery Movement Control Order (PKPP) and the Conditional Movement Control Order (PKPB). The Royal Malaysian Police (PDRM) stated that 3,080 cases were reported from May 18 to October 2020. The Women's Aid Organization (WAO) found that the WAO service line increased 3.4 times during the period of movement via phone calls, WhatsApp application queries through the WAO hotline. According to Saadah and Shuhada (2018), domestic violence increases every year due to a lack of public exposure to the rights that can be fought for if a person experiences domestic violence. The increasing statistics of domestic violence cases is a greatly worrisome social problem in all levels of society regardless of race, class, and economic status. 
Table 1: Statistics of Violence Against Women in Malaysia

Domestic

\begin{tabular}{cc} 
Year & Violence \\
\hline 2010 & 3,173 \\
2011 & 3,277 \\
2012 & 3,488 \\
2013 & 4,123 \\
2014 & 4,807 \\
2015 & 5,014 \\
2016 & 5,796 \\
2017 & 5,513 \\
2018 & 2,276 \\
\hline
\end{tabular}

Table 1 shows the statistics of violence against women in Malaysia from 2010 to May 2018 released by the Royal Malaysian Police (PDRM). Referring to domestic violence cases that were reported in 2010, a total of 3,173 cases were recorded followed by 3,277 cases in 2011 and 3,488 cases in 2012. The increase continued in 2013 with 4,123 cases followed by 4,807 cases in 2014. In 2015, the number of reported cases increased to 5,014, followed by 5,796 cases in 2016 and 5,513 cases in 2017. At least 2,276 cases of violent households were reported from January to May 2018 (PDRM, 2018). According to Ibrahim (2009); Azli (2010), violence can be equated with discrimination committed in five forms namely physical, psychological, emotional, sexual, and financial. The Convention on the Elimination of All Forms of Discrimination Against Women (CEDAW) defines violence against women as any act of gender-based violence that causes or is likely to cause psychological, sexual, or physical abuse or suffering to women, including threats to commit the previously described acts, coercion or arbitrary acts, depriving liberty, whether committed in public or private life (WAO, 2013).

According to Act 521, domestic violence is defined as an action or more intentionally or knowingly committing an action that could cause physical injury, intimidation, sexual as well as being the cause of psychological stress to the victim either the husband or wife, ex-husband or ex-wife, children, disabled adults as well as other family members (AKRT, 1994). According to Makmor Tumin (2004) in the mid-1980s, gradually the awareness of certain parties especially women NGO activists consisting of several affiliated members of the National Council of Women's Organizations Malaysia (NCWO) began to be actively involved in identifying issues and the problem of domestic violence until the proposal of enacting an act, the Domestic Violence Act (AKRT) 1994. This was because of the awareness that domestic violence can no longer be a personal problem or an individual issue, but rather a community problem. Therefore, there is a call from various quarters that domestic offenses should not be seen as mere civil cases but should be addressed and considered as social crimes because domestic violence is more dangerous than other societal crimes, where the perpetrator lives side by side with the victim (WAO, 1997).

The Domestic Violence Act 1994 (Act 521) which came into force on 1 June 1996 seeks to give special attention to cases of domestic violence as a form of legal protection to victims of family member abuse and matters incidental thereto. This protection includes the protection provided to the victim from continuing to be exposed to the threat of abuse. The Act was subsequently amended through the Domestic Violence (Amendment, 2012) Act A414 and 
came into force on 20 February 2012. The definition of domestic violence is extended from physical abuse to psychological abuse and the use of intoxicating or other substances that cause delusions to victims. The amendment to Act 521 also provides for additional protection consisting of an Interim Protection Order (IPO) or a Protection Order (PO) (AKRT, 2012). In September 2017, the Domestic Violence Act (Amendment) 2017 was gazetted. There were five main issues given attention in this amendment including expanding the definition of domestic violence and the introduction of an emergency protection order (EPO) as well as allowing the Act to be read in conjunction with the Penal Code or any written law involving offenses related to domestic violence. The amendments were made in line with the increase in domestic violence cases in Malaysia and with the hope that more victims would come forward for protection. But the question now is, to what extent the implementation of this Act is used to provide protection and defense for the victims who come forward to report cases of domestic violence (Domestic Violence Act, 2017).

A study by the Center for Women and Gender Research (KANITA, 2014) at Universiti Sains Malaysia found that 9 out of 100 women who have ever had a partner experienced domestic violence at some point in their lives. Although this percentage seems small, the total percentage when applied to the population in Malaysia clearly shows a significant number of domestic violence cases in society especially when compared to cases reported annually (Shuib et al., 2013). In 2015, the Ministry of Women, Family, and Community Development has introduced Talian Kasih, and from 31 May 2015 to 2018, the number of complaints received was 2,212 total complaints (KPWKM, 2018). Regarding the current situation from the legal point of view, is it necessary for the authorities to amend the Domestic Violence Act 1994 by placing the responsibility of reporting incidents of domestic violence as a compulsory matter, namely "mandatory reporting". A helpline established by the Ministry of Women, Family, and Community Development aims to give awareness to victims to report directly and get immediate help. Not only that, the Women's Aid Organization (WAO) has also introduced a complaints line that uses the WhatsApp application, Think I Need Aid (TINA) for victims to share the problem of domestic violence cases. According to Charlene Murray, WAO Case Manager, a total of 1,640 calls were received in 2016 and 2,078 calls in 2017. The App became the fastest medium as WAO can always be contacted (Berita Harian Online, 2018).

Shortcomings in the implementation of the Act and subsequent follow-up services made an operating procedure necessary for domestic violence to be introduced on 16 December 2015 aimed at detailing the functions of the main agencies involved in handling domestic violence reports. Technical agencies involved are the Attorney General's Chamber, Department of Social Welfare (JKM), Royal Malaysia Police (PDRM), Courts, Department of Islamic Development Malaysia (JAKIM), State Islamic Departments (JAIN), Ministry of Health (KKM), Ministry of Higher Education (KPT), Department of Women's Development (JPW), and National Population and Family Development Board Malaysia (LPPKN). Along with that awareness and concern, various manifestations of domestic violence can be seen with the proliferation of various columns in numerous mass media that discuss problematic issues related to gender issues in general and domestic violence in particular. In addition, this guideline was designed to provide information to the agencies involved in the management of domestic violence cases related to the roles and responsibilities of each agency. 
The guideline developed was an initiative of the Ministry towards closer cooperation between all agencies. The standing of each agency is very important in creating core cooperation so that cohesive case reporting methods can be achieved, thus reducing cases of domestic violence as well as assistance can be provided comprehensively, efficiently, and effectively. This clearly shows that the technique of reporting domestic violence cases is very important in addressing the issue of domestic violence and most cases do not get proper defense (KPWKM, 2015). The extent to which social workers are competent in managing the reporting of domestic violence cases needs to be studied. This is because social workers in the Department of Social Welfare play an important role in assisting victims as stated in section 2 of Act 521, Enforcement Officers consist of Social Welfare Officers. Therefore, social workers who handle these reporting cases should have specific training in handling domestic violence case reporting as prescribed by the case handling guideline. Lack of knowledge and inadequate training in case handling skills can be the cause of a report not being successfully prosecuted. Not only that, the lack of skilled social workers is also a reason why the competencies of social workers cannot be met. Moreover, many women decide not to take action to report cases for a variety of reasons. Among them is the lack of awareness of the welfare services that exist in helping domestic violence victims. According to the Women's Aid Organization (WAO) 2017, out of 110 women surveyed, 91 women did not go to the Social Welfare Department for help due to a lack of knowledge about the role of the Social Welfare Department itself. In response to this problem, researchers attempted to explore the procedures to help victims of domestic violence in making case reports.

\section{Methodology}

This study used the qualitative study design based on a phenomenological approach to explore in-depth the procedures of reporting domestic violence cases, as reported by the victims and responsible bodies such as police, medical officers, lawyers as well as NGOs involved. Phenomenology is an approach to explore people's daily life experiences. A researcher of phenomenology investigates subjective phenomena (Creswell, 2009). The study location is Hulu Langat district, in Selangor, Malaysia. The state recorded the highest number of domestic violence complaints at 1,304 through Talian Kasih and Talian Nur which are operating at KPWKM.

The informants are several parties responsible for handling the issue, namely police officers, social welfare officers, medical officers, and lawyers. They were selected to be interviewed as people with authority to explore their perspectives and roles in addressing the problems faced by victims of domestic violence. The backgrounds of the informants are as in Table 2 . This study uses thematic analysis emphasizing specific themes that aim to explore in detail and prove the themes. The thematic analysis aims to understand a phenomenon by emphasizing a complete picture related to the phenomenon under study. 
Table 2: Demographic backgrounds

\begin{tabular}{|c|c|c|c|c|c|}
\hline Informant & Sex & Age & $\begin{array}{c}\text { Marital } \\
\text { status }\end{array}$ & $\begin{array}{c}\text { Educational } \\
\text { level }\end{array}$ & Occupations \\
\hline 1 & Female & 26 & Divorced & Degree & Graphic designer \\
\hline 2 & Male & 34 & Married & Diploma & JKM Officer \\
\hline 3 & Female & 30 & Married & Degree & Doctor \\
\hline 4 & Female & 36 & Married & Degree & Police \\
\hline 5 & Female & 59 & Divorced & PHD & Lawyer \\
\hline
\end{tabular}

\section{Results and Discussion}

The domestic violence reporting techniques that will be discussed in this section include several procedures that have been identified to help victims of domestic violence in making case reports. In this study, researchers have summarized four procedures in reporting cases of domestic violence that occur either on themselves or on people around them. Among them are injury identification, client interview, violence assessment, and case reporting.

\section{Injury Identification}

Any injuries that occur to the victim should be identified in advance before a case report is made. This is to ensure that the recorded reports have strong and factual evidence. Not only that, but this technique of identifying signs of injury is also an important alternative for each individual in identifying friends or close family who may be victims of domestic violence. This is since most victims involved in domestic violence cases prefer to keep the events private from the public due to anxiety and being afraid of the event recurring becoming more complicated. Some individuals feel the domestic violence is a personal problem and a disgrace to be reported to the public especially involving sexual violence (Hoesni \& Zakaria, 2019).

Signs of injury can be identified through detailed observation of the physical injuries suffered by any victim of domestic violence. However, medical treatment is also needed to assess the severity of the injury. Informant 1 stated that the physical injuries suffered had left an impact on the informant's body including bruising and painful body parts. According to Informant 2, identifying injuries that occurred to the victim who came for help was done by referring the victim to the medical officer at the hospital who helped in diagnosing the injuries. "The observations we make, only the physical injuries we see. Kind of swelling, bloody face, deep bleeding eyes, swelling in the hands, in the legs, that's all... only a medical officer can make a diagnosis. Stress involving mental damage, internal damage, internal injuries, sometimes broken ribs but we don't see, she/he said it hurts ... it hurts but we don't know. She/he has something broken internally; we will ask her/him to refer to a medical officer" (Informant 2/JKM Officer).

In addition, the results of interviews with Medical Officer showed that for physical injuries, the effects experienced by the victim were bruises, wounds, and fractures. On the other hand, psychological and sexual injuries will create emotional disorders such as depression, anxiety, fear, and trauma to the individual. For emotional and sexual injuries, the individual should undergo medical treatment after being diagnosed by a medical officer. This is because emotional and sexual injuries are difficult to detect with naked eyes. Right of Women (2014) states that the sooner a victim reports sexual violence to the police, the easier it is for the police to obtain evidence that can aid the prosecution of the perpetrator. It is essential for 
victims suffering from emotional disturbances because of psychological abuse to seek medical treatment and be diagnosed by a psychiatrist. This is because the psychological abuse that takes place is difficult to be detected with naked eyes and requires detailed treatment to see the severity of the emotional stress experienced by the victim. According to Informant 3 and Informant 5, a psychiatric report is essential in accessing the level of emotional abuse that has occurred to individuals who have been victims of domestic violence. Based on the information obtained, it can be concluded that the technique of identifying signs of physical injuries can be identified with naked eyes. Meanwhile, psychological and sexual injuries require the victim to seek medical treatment.

\section{Client Interview}

Based on the results of the study, the researchers found that in recording domestic violence case reports, victims of violence will go through several pre-determined bureaucratic proceedings. Client interviews will be conducted to obtain information related to domestic violence. Women Aid Organisation (WAO) 2017, in its study, stated that after the victim files a report at the police station, the police investigating officer will interview the victim before the Interim Protection Order reference letter is issued to a welfare officer (JKM) for application to the Court. According to Informant 1, the police officer who recorded the case report had conducted interviews with the informant. The informant stated that interviews were conducted during the investigation of the case and all the statements of the victim were recorded during the investigation. "Police officers will interview and record the session before the investigating officer can issue a case confirmation letter to apply for an IPO." (Informant 1 /Victim). JKM officer stated that the client who comes to obtain a Protection Order will be interviewed before the application is carried out. The JKM officer who is assigned to manage domestic violence cases will consult the victim to find out the purpose of the Protection Order.

"Once a police report was done, we will ask if the victim wanted a divorce or what is the purpose of making this police report. Some just wanted to give awareness to the husband. Some of them wanted to get divorced, they really wanted to get divorced, so they are serious. Sometimes when we consult, she is not happy, she wants protection, but she does not want the husband to be penalized." (Informant 2/JKM Officer). Further, Informant 3 clarified that domestic violence victims who lodge a police report will be referred to the Investigating Officer (IO) of the Sexual, Women and Children Investigation Division (D11) for consultation before a Protection Order is applied for. Every statement made by the victim during the investigation will be recorded. She further explained: "the victim will then be referred to the Investigating Officer (IO) at the Sexual, Women and Children Investigation Division (D11) where the victim makes a complaint. The $I O$ will take the details of the incident. A recording will be done to capture the victim's testimony. A police statement is used to investigate the case" (Informant 4/Police Officer).

\section{Violence Assessment}

A violence case assessment is needed to gauge the extent of the severity that has befallen the victim. In assessing the injuries that occurred, a medical report is required as evidence of the abuse. This is important for the court to enact a sentence on the perpetrator. Farai Syposz (2017) in the Right of Women study stated that evidence is needed by victims to support their application in seeking legal aid. Based on the study, it was found that medical treatment will be given to victims of violence according to the critical stage of a case. There are two 
categories of cases namely non-critical and semi-critical or critical. Not only that, further medical treatment will also be given to the victims who suffered serious injuries. This clarifies that the assessment of violence is done according to the category of the case.

"This case falls into two categories, one non-critical. The victim will be escorted to the examination room or treatment room for examination for treatment and initial counseling. The second case is semi-critical or critical. The patient will be given immediate treatment and will be admitted to the ward once stable. Patients will be referred to a social work officer or counselor or psychiatrist for trauma cases, if necessary. Further medical treatment will be given to victims who suffer serious injuries or problems" (Informant 3/Medical Officer).

According to Informant 2, punishments or fines will be imposed under the provisions of the Domestic Violence Act. In addition, the Lawyer also clarified that the court would look at the level of violence of the case to make a decision. A medical report is required to assess the level of physical, psychological, and sexual violence. The informant justified; "If the first-time offender is guilty of an offense under the Domestic Violence Act, this is where the court will give a fine as the first warning. But if, for example, say the second or third offense, he will be imprisoned." (Informant 2/JKM Officer). Meanwhile, according to informant 5, assessments of violence were done to measure the severity of a case of violence before the Court sentenced the perpetrator. This assessment will be used as evidence in convicting the perpetrator in abusive relationships. The worse the degree of severity of the abuse, the heavier the punishment that will be imposed on the perpetrator, and all those punishments depend on the related provisions of the Act. From the court's perspective, the degree of severity in terms of physical to emotional, emotional disturbance, or psychological abuse is very important for the court in measuring the severity of the case (Marziah et al., 2019).

\section{Case Reporting}

Report is a document that presents information in an organized format in the form of a written document that plays a role in recording information for a specific purpose. In the case of domestic violence, there are several requirements for technical agencies such as police, medical officers, and JKM officers to document case complaints reported by victims of violence. It is to ensure that detailed information related to complaints made by victims can be collected and adjudicated accordingly. Women's Center for Change (2013) elaborates on the need for victims to report a crime to enable the investigation and prosecution process to be carried out by the court. When a crime occurs, the victim or the family members should report the crime to the police station. This is because the journey towards achieving justice will begin when a police report is lodged. The Domestic Violence Act has provided for three types of Protection Orders that victims of domestic violence can apply for. These are Interim Protection Order (IPO), Protection Order (PO), and Emergency Protection Order (EPO).

Based on the interview with Informant 1, the researcher found that a police report should be made before the informant sought treatment in the hospital. During the police report, the informant was asked to provide detailed information related to the incident to the police to enable the investigation paper to be carried out. Among the documents required when making reports are the victim's identity card and marriage certificate. Informants will also be asked to undergo medical treatment at a nearby hospital by bringing the police referral letter. Then, the informant's divorce process is applied through the legal aid bureau's consulting 
services. There are several documents required to lodge a report. These written documents are important as a reference that can be brought to court to obtain a Protection Order. "The officer asked for my identity card, marriage certificate. The officer on duty asked me to give an account of what happened. Then he asked me to go for medical treatment. He gave me a form for the doctor to fill out. To get an interim protection order (IPO), have to make a police report first, the police officer will interview, and the recording of the interview will be recorded, and the investigating officer will issue a case confirmation letter to apply for the IPO. The IPO application is made at the JKM district." (Informant 1/Victim).

Informant 2 stated that the application for a Protection Order will only be done at the Social Welfare Office after the investigation paper is conducted by the Investigating Officer (IO). There are three ways to make an application, the first is for the client to come directly to the JKM Office. Second, the client is referred by the police, and third through the Kasih 15999 phone service. Next, before the application is carried out, the client will be given a consultation to find out the purpose of the application. The client will also be given consultation regarding the possibilities that will occur after the application for the Protection Order is carried out. Among the documents required for the application for a Protection Order at JKM is a police confirmation letter to apply for an IPO, marriage certificate, victim's identity card, perpetrator's identity card if any, children's identity cards, or birth certificates. In addition, according to Informant 2, clients can obtain an Emergency Protection Order (EPO) at the JKM office. The EPO application aims to provide immediate protection to the victim at any time including after office hours. In this instance, the application does not require a police report. Clients can get through the Nur line which operates 24 hours or from the district JKM office. This EPO will be in effect for a period of one week. "The emergency protection order (EPO) can be applied directly at JKM without having to make a police report. EPO will be issued within 24 hours for victims who are at risk of being physically injured or have been physically abused." (Informant 2/JKM Officer). Furthermore, according to Informant 3, if a patient or victim seeking medical treatment wishes to apply for a medical report, the patient must follow certain procedures recommended by the Hospital Records Division. Medical reports will not be charged if the patient applies through the police, JKM, and the Legal Aid Department.

A police report can be made at any district police station by the victim or a witness of the incidence of violence taking place. After a police report was made, the victim will be asked to provide a detailed statement about the incident by an Investigating Officer (IO) assigned to investigate the crime. Victims or witnesses will be interviewed to take detailed evidence. If the crime is a sexual crime such as rape or domestic violence, the victim will be taken to One Stop Crisis Center (OSCC) at the Emergency and Trauma Unit of a government hospital for medical examination and for the collection of evidence of the crime. Evidence collection will involve interviews with victims or witnesses, physical evidence gathering, visits to the scene of the crime, and written evidence as well as expert reports by the doctors examining the victim. According to informant 4, several documents are required when making a police report, namely the victim's identity card, marriage certificate, copy of the children's identity card or birth certificate if any and a medical report if any. To record a police report, detailed statements regarding the abuser's treatment of the victim must be clearly stated. Information such as date, time, location, and who was involved as well as the impact to the victim should be stated. Form 59 will be given to the victim for medical treatment. The report made will cost 
RM4.00 and a copy of the report will be given to the victim. After the investigation paper is conducted, the Investigating Officer will issue a reference letter to apply for an IPO at JKM.

Informant 5 in the interview explained that victims of domestic violence can seek assistance through the Legal Aid Department which acts as an advisor to help victims file complaints in court. For applications in the legal aid department, several documents are required such as identity card, marriage certificate, birth certificate, child's birth certificate, police report, medical report, and counseling report if any. The role of the court is to register and hear applications for Protection Order (PO) and Interim Protection Order (IPO). Once the case is heard in court, the court will decide based on the provisions of the law that have been set. Overall, the techniques required in recording domestic violence case reporting include several elements, namely violence identification, client interviews, violence assessment, and case reporting. All these techniques are required to be met when reporting to the authorities. There are four main proceedings in domestic violence reporting techniques that victims of abuse must go through in reporting the cases. Among them is identifying the signs of injuries suffered by victims of abuse. This can be classified through women's knowledge of the types of domestic violence that may occur to them. Signs of these injuries can be identified through tests in the hospital. Each injury has its own set of symptoms. Through an understanding of the types of violence, then the process of identifying injuries that occur to victims is much easier. Every individual who serves a victim of abuse needs to understand each sign of injury. This is because some victims prefer to take the approach of keeping the events private. Signs of injury can be identified as the victims undergo medical treatment and are diagnosed by physicians (Zakaria et al., 2020).

Moreover, the researcher found that interviewing clients is one of the techniques of reporting domestic violence cases, where clients will be interviewed to obtain and collect information related to abuse that has occurred. The results of the study found that there is a need for police officers on duty to conduct interviews with clients. Interviews are conducted for case investigation and all statements issued by the victim will be live recorded during the interview. In addition, the JKM officer on duty will also interview the victim before the Protection Order is applied. This aims to detail out the purpose of obtaining the Protection Order. Therefore, once signs of injuries are identified and interviews are conducted by the officers on duty, an assessment of the violence will be conducted to see the severity of the violence that has occurred on the victim. This assessment of violence is based on the medical report which verified that the case of abuse has occurred. This is because punishment will be imposed on the perpetrator based on the assessment of violence. This explains that medical reports are important in assessing levels of physical, psychological, and sexual violence.

There are two categories of case violence namely non-critical and semi-critical or critical (Ibrahim et al., 2019). For semi-critical or critical cases, the victim will be given immediate treatment and will be admitted to the ward when stable. Further treatment will also be given to victims who have suffered semi-critical or critical injuries. Not only that, the results of the study also showed that the level of violence in the case is an important factor considered by courts in sentencing. The last technique required in recording a case is the reporting of the case itself. Based on the study, case reporting is a method used by technical agencies such as police, medical officers, and JKM officers to record information resulting from case complaints reported by victims of abuse. Each technical agency has its specific proceedings in recording 
complaints. The researcher found that there are several documents required in ensuring that the case report meets the specifications set by the bureaucracy that provides the service. Documents such as the complainant's identity card and marriage certificate are important documents that should be brought along when making a complaint.

This indicates that victims of abuse need to be sensitive to the need for such documentation before making a complaint. The application for protection can only be done if the victim brings documents such as identity cards, IPO confirmation letters, marriage certificates, and children's identity cards. This is subject to the provisions set by the technical agency in ensuring that when the application is brought to court, there will be no rejection due to incomplete documentation (Alavi et al., 2020). In short, the findings of this research can be summarized as following:

Table 3: Sources of themes

\begin{tabular}{lcl}
\hline & Themes & Sources \\
\hline 1. $\quad$ Injury identification & Informant 1 \\
& & Informant 2 \\
& Informant 3 \\
& & Informant 5 \\
& Client interview & Informant 1 \\
2. Informant 2 & Informant 3 \\
& & Informant 4 \\
& & Informant 3 \\
3. $\quad$ Violence & Informant 2 \\
assessment & & Informant 2 \\
& & Informant 5 \\
& & Informant 1 \\
4. Case & reporting & Informant 2 \\
technique & & Informant 3 \\
& & Informant 4 \\
& & Informant 5 \\
\hline
\end{tabular}

\section{Conclusion}

This study found that the domestic violence case reporting technique is a chain of processes required by victims of domestic violence to get out of a situation of violence. Through this study of domestic violence case reporting techniques found that victims of violence need to have knowledge and understanding in reporting cases experienced by victims before making a complaint of abuse cases that have been committed by abusers. Most victims of abuse lack the awareness to immediately report cases of abuse after being abused especially those involving sexual abuse. When victims do not take steps to immediately report cases due to embarrassment and trauma, this makes it difficult to identify the type of violence that occurs because the evidence available on the victim's body may be long gone. This study suggests ways to improve quality in delivering services by establishing effective working policies. In dealing with client problems, effective communication in supporting victims is very important. Problem assessment is a critical process because comprehensive information must be gathered first, wherein problem assessment where the social worker needs to use theoretical 
concepts to understand the problems presented by the client. In addition, the parties involved also need to increase the systematic monitoring from superiors and take appropriate actions to improve the quality of services provided. The study also suggests integrated online reporting between victims, JKM officers, police, and medical officers up to the court levels to ensure the consistency of victim complaint information is reached more accurately without victims having to repeatedly convey a traumatic case both to victims and their families.

\section{References}

Akta Keganasan Rumah Tangga (Pindaan) Malaysia. (2017). Akta Keganasan Rumah Tangga 1994 (Pindaan) 2017. (Akta A1538).

Akta Keganasan Rumah Tangga Malaysia. (1994). Akta Keganasan Rumah Tangga 1994. (Akta 521).

Akta Keganasan Rumah Tangga Malaysia. (2012). Akta Keganasan Rumah Tangga 1994 (Pindaan) 2012. (Akta A1414).

Creswell, J. W. (2009). Educational Research: Planning, Conducting, and Evaluating Quantitative and Qualitative Research. New Jersey: Pearson Prentice Hall.

Syposz, F. (2017). Research investigating the domestic violence evidential requirements for legal aid in private family disputes. Ministry of Justice, 1-97.

Ibrahim, I., Zakaria, E., Sarnon, N., Nen, N., \& Hassan, N. (2019). Relationship between emotional disturbance, family conflict, social pressure and drug craving among former drug addicts. International Journal of Recent Technology and Engineering, 8, 43-47.

KPWKM. (2015). Garis Panduan Pengendalian Kes Keganasan Rumah Tangga. Retrieved from https://www.kpwkm.gov.my/kpwkm/uploads/files/KenyataanMedia/.

KPWKM. (2018). Jumlah aduan diterima mengikut negeri bermula Disember 2007 sehingga Julai 2018. Retrieved from https://www.data.gov.my/data/ms_MY/dataset/jumlahaduan

Alavi, K., Hazlan, N. H., \& Johani, S. (2020). Exploring the gerontological skills competencies of social workers through vocational education and training in caring for the elderly. Pertanika J. Social Sciences and Humanities, 28 : 1401-1413.

Laporan Polis Diraja Malaysia (PDRM) (2018). Statistik Keganasan Terhadap Wanita di Malaysia. Data.gov.my.https://www.data.gov.my/data/ms_MY/dataset/statistikkeganasan-terhadap-wanita-di-malaysia/resource/d5f6eecd-5da5-4a6f-8244$86926665 f \mathrm{fc} 4 \mathrm{f}$

Ishak, M., \& Sazale, N. A. (2017). WAO tingkatkan kesedaran bela wanita teraniaya. Berita harian 16 Mac 2017. https://www.pressreader.com/malaysia/berita-harianmalaysia/20170316/281934542758726

Ishak, M. (2018). Aplikasi TINA bantu mangsa keganasan rumah tangga. Berita Harian Online. 10 Julai 2018.https://www.bharian.com.my/wanita/lain-lain/2018/07/447248/aplikasitina-bantu-mangsa-keganasan-rumah-tangga [30 September 2019]

Tumin, M. (2004). NGO Wanita dalam sistem politik Malaysia: Kajian mengenai kegiatan Majlis Kebangsaan Pertubuhan-Pertubuhan Wanita Malaysia (NCWO). Universiti Malaya Student Repository. Vol:1 (1-2)

Pertubuhan Pertolongan Wanita. (1997). Monitoring the Domestic Violence Act (1994) Malaysia: A report by Women's Aid Organisation. hlm 5. Petaling Jaya: Women's Aid Organisation (WAO). 
Pertubuhan Pertolongan Wanita. (2013). CEDAW \& MALAYSIA: Laporan Alternatif Pertubuhan-Pertubuhan Bukan Kerajaan (NGO) Malaysia. Petaling Jaya: Penerbit Pertubuhan Pertolongan Wanita (WAO), 213-226.

Polis Diraja Malaysia. (2018). Statistik Keganasan Terhadap Wanita di Malaysia. Retrieved from https://www.data.gov.my/data/ms_MY/dataset/jumlah-aduan-diterimamengikut-negeri.

Ibrahim, R. (2009). Tahap kemurungan dan konflik isteri yang didera. Jurnal ILIM, 2:51-73.

Shuib, R., Enduta, N., Alib, SH., Osmana, I., \& Abdullah, S. (2013). Domestic violence and women's well-being in Malaysia: Issues and challenges conducting a national study using the WHO multi country questionnaire on women's health and domestic violence against women. Procedia-Social and Behavioral Sciences, 91: 475-788

Right of Women. (2014). From Report to Court: A handbook for adult survivors of sexual violence. Right of Women.

Saadah, M. A., \& Shuhada, M. M. (2018). Pengetahuan mahasiswa tentang perundangan dalam keganasan rumah tangga. Jurnal Personalia Pelajar, 21(1):37-42.

Azli, S. (2010). Menangani keganasan terhadap wanita dari perspektif undang-undang dan gender. Kertas kerja Bicara Undang-undang. Anjuran Mahkamah Syariah Wilayah Persekutuan Kuala Lumpur.

Shuib, R., Ali, S. H., Abdullah, S., Ab Ghani, P., Osman, I., Endut, N., Shahrudin, S. S. (2014). Executive Report: A Country Level Study of Women's Well-being and Domestic Violence Against Women (AKRTW) Using WHO Multi-country Questionnaire. Pulau Pinang: Women's Development Research Centre (KANITA), University Sains Malaysia.

Zakaria, S. M., Lazim, N. H., \& Hoesni, S. (2019). Life challenges and mental health issues of single mothers: A systematic examination. International Journal of Recent Technology and Engineering, 8: 48-52.

Zakaria, S. M., Akhir, N., Ebrahim, M., Rahmat, H., \& Hoesni, S. (2020). Dual-role women in Selangor: Work-family conflict and its impact on emotional wellbeing. International Journal of Psychosocial Rehabilitation, 24 : 4103-4114.

Hoesni, S., \& Zakaria, S. M. (2019). Marital satisfaction and general happiness among urban Malays in Klang Valley. International Journal of Recent Technology and Engineering, 8 : 97-101.

WAO. (2015). Working Together: Case studies in domestic violence response 2015 Report. Petaling Jaya Selangor.

WAO. (2017). Laporan penyelarasan gerak balas komuniti terhadap isu komuniti. Petaling Jaya Selangor.

Women's Centre for Change (WCC) (2013). Menghadapi Proses Mahkamah: Panduan untuk Memahami Proses Mahkamah Jenayah, 1-52. 